\title{
FLOUTING MAXIM OF QUANTITY IN THE CHARACTERS' DIALOGUES IN “DETECTIVE PIKACHU” MOVIE
}

\author{
Desri Lestari $^{1}$ and Dadan Firdaus ${ }^{2}$ \\ UIN Sunan Gunung Djati ${ }^{1}$, Bandung, rdezrie@gmail.com \\ UIN Sunan Gunung Djati ${ }^{2}$, Bandung, dadanfirdaus@uinsgd.ac.id
}

\begin{abstract}
Detective Pikachu movie, a family genre movie, has universal cultural identity across countries even continents which is representative to internationally accepted movies through all ages and culture. Communication between speakers and listener should fulfill maxims in order to have an effective communication and to avoid misunderstanding. The research uses Grice's theory of the Cooperative Principle in order to describe the communication that happens among the characters in the movie. The purpose of this research is: to find out maxim of quantity flouted in the characters' dialogue in Detective Pikachu movie and to find out the other characters involved in the dialogue respond to this flouting maxim of quantity. The obtained data were analyzed with descriptive qualitative method. As the findings, there are 30 data flouting maxims of quantity has flouted in the characters dialogue in Detective Pikachu movie. Almost all of the characters in the movie flouted the maxim of quantity. The characters are said to be flouting the maxim of quantity because they are in the dialogue that occurs. They are too much or too little in providing information. When viewed from the comparison of the dialogue in the movie, giving too much information is more often done by the characters than giving too little information. the other hearer responds to the speaker who flouted the maxim of quantity is not to be bothered by this because it is helped by the implicature, insights and experiences of the characters so that the dialogue can still work well.
\end{abstract}

Keywords: Pragmatics; Cooperative Principle; Flouting Maxim

\section{INTRODUCTION}

Detective Pikachu movie, a family genre movie, has universal cultural identity across countries even continents which is representative to internationally accepted movies through all ages and culture. This movie is easy watching so that the use of language that usually should be understood by many people with different ages and cultural backgrounds. Therefore, this movie as the object of research of how the people use language for interaction is suitable since the movie should reach all kinds of viewers (universal).

In terms of the interaction, as human beings we need to interact socially or communication with other human beings. The communication process can be done in writing or verbally. There is a difference between the use of written language and oral language. When someone uses written language, the language used is in formal format and pay attention to the grammar used, whereas when the oral 
language is used, the speaker tends to pay more attention to how so that the contents of the dialogues are conveyed well rather than pay attention to the grammar of the resulting dialogue.

In a communication, the speaker will deliver a certain message that delivered through language and the hearer will try to capture the meaning of the message delivered. So, to create a good communication, then between the speaker and the hearer must understand each other well. One basic of the communication is conversational. In a conversational, there are two essential roles taking part. They are speaker and hearer exchange their roles.

According to Levinson (1983) a conversation as a familiar predominant kind of talk where two or more people freely alternate in speaking that commonly occurs outside some institutional settings like religious service, law courts, classroom, etc. Therefore, in order to achieve a successful communication, especially in the verbal section or conversation, participants are expected to be able to cooperative.

A successful and good conversation can happen if the speaker and the hearer can understand each other's dialogue. According to (Grice H. , 1989), there is an agreement between the speaker and hearer to have a successful conversation, namely Cooperative Principle, which says: "Make your conversational contribution such as is required, at the stage at which you are engaged" (Grice H. , 1989). One of the most basic assumptions people must make for successful communication to take place is that both people in a conversation are cooperating. This is called the Cooperative Principle. Basically, the Cooperative Principle explain that in conversation every participant must give contribution well.

In this principle, there are four maxims that must be applied for creating a good communication. Conversational Maxims proposed by Grice (1989), they are; maxim of quantity, maxim of quality, maxim of relevance, and maxim of manner. In order to obey the Maxim of Quality, the speaker should make true contribution. The speaker is considered to fulfill the Maxim of Quantity if he or she makes a contribution as informative as it is required. The speaker can fulfill Maxim of Relation if his/her contribution is relevant. If the speaker wants to follow the Maxim of Manner, he or she should be perspicuous.

In fact, the four maxims in conversational are not always obeyed by the participants. When the maxim is not followed or obeyed in a conversational, then this is called Flouting Maxim. According to Thomas (1995) when flouting a maxim, the speaker does not intend to mislead the hearer but wants the hearer to look for the conversational implicature, that is, the meaning of the utterance not directly stated in the words uttered. Therefore, when the speaker intentionally fails to observe a maxim the purpose may be to effectively communicate a message.

From that stated, it can be concluded that when the participants flouting the maxim in conversation, he hopes that the hearer can capture the meaning of the words where the message he wants convey it cannot be stated explicity. In this case 
the phenomenon of flouting maxim can be seen not only in real life but also in movies.

Movies are type of visual communication which use moving picture and sound to tell stories or teach people something. Thompson (1997) states that movies are equal with buildings, books, and symphonies. It is an artifact that is made by humans for human's purposes. Movies have some aspects which can reflect the phenomena clearer than other media. In movies, unlike in novels, the phenomena are depicted clearer through the context, setting, facial expression, and the like.

\section{LITERATURE REVIEW}

Cooperative principle, the umbrella encompassing the theory of maxims quantity, is needed to be present in a communication, in a particular situation with a certain condition or context involved, a speaker might intentionally flout it (Grice, 1989). The reason as to why someone would violate a maxim may vary, ranging from a possibility that they may wanted to hide the truth, to save face, they feel jealous, to satisfy or cheer the hearer, to avoid hurting the hearer, or to simply convince the hearer.

\section{Flouting of Maxims}

Flouting of maxims is an act of violation committed by a speaker in a conversation that deviates from the principle of cooperation or the rules of language use. Flouting of maxims often occurs in everyday conversation. Speakers sometimes deliberately do flouting of maxims, because speakers have goals and objectives to be achieved and expect their interlocutors to understand what the speaker means. Cutting (2008: 36) suggests that the flouting maxim is unostentatiously. The speaker deliberately supplies insufficient information, says something that is insincere, irrelevant or ambiguous and the hearer wrongly assumes that they are cooperating. The following are examples of flouting of each maxim:

1. Flouting maxim of Quantity

Grice (1989) stated that the flouting of the maxim of quantity may happen if the speaker intentionally gives more or less information than what is really needed. Look at the example below:

Boy: What are you going to buy?

Mat: Well, I'm gonna buy some vegetables at the supermarket with my mom's new car.

The example above shows that Mat already giving too much information than what is asked for by Boy. The required information is "I'm gonna buy some vegetables at the supermarket." However, the speaker adds an unwanted information by saying "using my mom's new car". 
2. Flouting Maxim of Quality

Going by the definition of the maxim itself, it means that the speaker intentionally did not tell the truth, or simply refuse to say the truth. For instance; Bob had a 50 score on his last exam, and when he got home, his mother asked him about his score.

Mom: How many you got on the last exam, Bob?

Bob: Well, not really bad, Mom.

From the above, Bob intentionally hides the fact that he got 50 on his exam by saying "not really that bad". Therefore, Bob had flouted the maxim of quality.

3. Flouting Maxim of Relation

Flouting on the maxim of relation will show that the second speaker did not give a relevant answer to the first speaker. For instance: Both Mary and John needed topresent their assignment to the teacher today.

Mary: Have you finish your assignment for today, John?

John: I have just came back from my mother las night and did not get enough sleep.

From the excerpt above, John had flouted the maxim of relation, because Mary asked whether he had completed the assignment or not, and the answer that he must give was either a yes or no. However, John answered her question irrelevantly by stating "I have just came back from my mother las night and did not get enough sleep.", which will raise a possible implication that John had not finish his assignment yet, albeit he did not answer it directly to her.

4. Flouting Maxim of Manner

On the case of the maxim of manner, a flouting may occur if the second speaker answer a question in an ambiguous way and uttered a sentence or a word not in a common way than how it is actually said. As an example: John had taken his girlfriend on a date last night, and Jenny ask where they went.

Jenny: Where do you take your girlfriend last night?

John: Oh, we went to a very beautiful and calm place, where we can sit down and watch the stars on the night sky together while being surrounded by the verdant trees.

In the above conversation, John had flouted the maxim of manner because he did not specifically mention where he and his girlfriend went last night. Instead of mentioning a specific location of where they went, he instead give a vague description of the place where he went.

\section{Implicature}

According to Brown and Yule (1983: 27), implicature is the elements outside of the text. If it is returned to the initial concept, it can be understood that the relationship between the two prepositions, speech and the implication is not an absolute consequence (Parker, 1986: 21). With something like that can really connect the action of the conversation so that the conversation can run effectively. 
Based on the concepts described previously, implicatures can be defined with the following characteristics: 1. Implications are not stated directly, 2. There is no absolute relationship with the embodied speech, 3. Includes extralinguistic elements, 4. Open interpretation, and 5. Occurs due to obedience or disobedience to the principle of cooperation in conversation.

Levinson (1983: 97-100) argues that implicature has four basic concepts, namely:

1. Implicature stands as a paradigmatic example of the nature and power of pragmatic explanations of linguistic phenomena.

2. The important contribution made by the notion of implicature is that it provides some explicit account of how it is possible to mean more than what is actually saide.

3. The notion of implicature seems likely to effect substantial simplifications in both the structure and the content of semantic descriptions.

4. Implicature, or at least some closely related concept, seems to be simply essential if various basic facts about language are to be accounted for properly.

\section{METHOD}

This research used descriptive qualitative approach since it emphasizes on the use of language phenomena in the context by interpreting data. In qualitative method, the data obtained can be in the form of interviews, observations, documents and audiovisual data, then in qualitative methods, the statistical analysis can be in the form of text and image analysis, and also statistical interpretation can be in the form of themes and patterns interpretation (Creswell, 2014, p.45).

The data source that will be used in this research is Detective Pikachu movie. The data in this study are oral data obtained from movie script. All conversations in the movie was listened to by the researcher to see which utterances or conversations contained the flouting maxim of quantity and how the other hearer responded.

\section{FINDINGS AND DISCUSSIONS}

The results of the research are divided into two sections. The first section presents and describe maxim of quantity flouted in the characters dialogue in Detective Pikachu Movie and in the second section presents the other characters involved in the dialogue respond to this flouting maxim of quantity.

The Maxim of Quantity Flouted in The Characters' Dialogue in Detective Pikachu Movie

The researcher has classified the data and found 30 data flouting maxim of quantity in the characters' dialogue, as follow: 
Table 1. The data findings The Maxim of Quantity Flouted in The Characters' Dialogue in Detective Pikachu Movie

\begin{tabular}{|c|c|c|c|c|}
\hline No & Character & Utterances & Timestamp & Implicature \\
\hline \multirow[t]{2}{*}{1} & Jack & Have you heard that? & \multirow{2}{*}{$\begin{array}{c}00: 03: 12 \\
- \\
00: 03: 14\end{array}$} & \multirow[b]{2}{*}{$\begin{array}{ll}\text { Tim } & \text { is } \\
\text { actually } & \\
\text { confused } & \text { by } \\
\text { what } & \text { he } \\
\text { heard. } & \end{array}$} \\
\hline & TIm & Something's close. & & \\
\hline \multirow[t]{2}{*}{2} & Jack & I'm worried about you. & \multirow{2}{*}{$\begin{array}{l}\text { 00:06:08 } \\
- \\
00: 06: 16\end{array}$} & \multirow{2}{*}{$\begin{array}{l}\text { Jack worries } \\
\text { that Tim is } \\
\text { friendless and } \\
\text { lonely. }\end{array}$} \\
\hline & Tim & $\begin{array}{l}\text { This again? } \\
\text { Ok listen, everyone } \\
\text { we know has left town } \\
\text { and now i'm leaving } \\
\text { too. }\end{array}$ & & \\
\hline \multirow[t]{2}{*}{3} & Jack & $\begin{array}{l}\text { What's the promotion } \\
\text { for an insurance } \\
\text { appraiser? } \\
\text { insurance appraiser? }\end{array}$ & \multirow[t]{2}{*}{$\begin{array}{l}00: 06: 22 \\
- \\
00: 06: 32\end{array}$} & \multirow{2}{*}{$\begin{array}{l}\text { Tim is a bit } \\
\text { confused and } \\
\text { only sought a } \\
\text { defense with } \\
\text { that answer. }\end{array}$} \\
\hline & Tim & $\begin{array}{l}\text { No actually that's two } \\
\text { steps up above where } \\
\text { i'm at right now. }\end{array}$ & & \\
\hline 4 & Yoshida & $\begin{array}{l}\text { If you don't mind me } \\
\text { asking, how come you } \\
\text { don't have a Pokemon? } \\
\text { I thought I remember } \\
\text { Harry saying you } \\
\text { wanted to be a Pokemon } \\
\text { Trainer when you were } \\
\text { young. }\end{array}$ & $\begin{array}{l}00: 11: 29 \\
- \\
00: 11: 34\end{array}$ & $\begin{array}{l}\text { Tim is do not } \\
\text { like when } \\
\text { someone asks } \\
\text { him about } \\
\text { Pokemon } \\
\text { friends. }\end{array}$ \\
\hline \multirow[t]{2}{*}{5} & Tim & Wait, what? & \multirow{2}{*}{$\begin{array}{l}00: 15: 01 \\
- \\
00: 15: 11\end{array}$} & \multirow{2}{*}{$\begin{array}{l}\text { Lucy is trying } \\
\text { to find } \\
\text { information } \\
\text { about Harry. }\end{array}$} \\
\hline & Lucy & $\begin{array}{l}\text { Harry was onto } \\
\text { something big. Real } \\
\text { big. And then all of a } \\
\text { sudden, his car } \\
\text { crashes over a bridge. } \\
\text { I think not. } \\
\text { Something's rotten, } \\
\text { and I'm gonna get to } \\
\text { the bottom of it. }\end{array}$ & & \\
\hline
\end{tabular}




\section{The Other Hearer Responds to The Speaker Who Flouted the Maxim of Quantity}

The researcher has found the data from the other hearer respond to the speaker who flouted the maxim of quantity, as follow:

Table 2. The Data Findings the Other Hearer Responds to The Speaker Who Flouted The Maxim of Quantity

\begin{tabular}{|c|c|c|c|}
\hline No & Character & Utterances & Timestamp \\
\hline 1 & Jack & $\begin{array}{l}\text { See, this is what i'm talking about. } \\
\text { My heart is pounding. Get down, get } \\
\text { down. }\end{array}$ & $\begin{array}{l}\text { 00:03:12 } \\
- \\
00: 03: 14\end{array}$ \\
\hline 2 & Tim & $\begin{array}{l}\text { Yeah but that's ok, you gotta do } \\
\text { what's best for you with the time that } \\
\text { you got. That's what i'm doing. You } \\
\text { know i'm crushing it at work. Gonna } \\
\text { get that promotion real soon. }\end{array}$ & $\begin{array}{l}\text { 00:06:08 } \\
- \\
00: 06: 16\end{array}$ \\
\hline 3 & Jack & $\begin{array}{l}\text { You are gonna make me throw up. } \\
\text { That's not a real thing. }\end{array}$ & $\begin{array}{l}00: 06: 22 \\
- \\
00: 06: 32\end{array}$ \\
\hline 4 & Yoshida & $\begin{array}{l}\text { I understand. } \\
\text { But, Tim, please don't put this all on } \\
\text { yourself. No one should go through } \\
\text { this type of thing alone. If you are } \\
\text { anything like your dad... }\end{array}$ & $\begin{array}{l}00: 11: 29 \\
- \\
00: 11: 34\end{array}$ \\
\hline 5 & Tim & $\begin{array}{l}\text { Hey, look, I barely know the guy. I } \\
\text { haven't seen him in years. }\end{array}$ & $\begin{array}{l}00: 15: 01 \\
- \\
00: 15: 11\end{array}$ \\
\hline
\end{tabular}

00:03:12 - 00:03:14

$\begin{array}{ll}\text { Jack } & \text { : } \\ \text { Tim } & \text { : }\end{array}$

Have you heard that?

\section{Something's close.}

See, this is what I'm talking about. My heart is pounding. Get down, get down.

Analysis

From the conversation above, Tim did a flouting maxim of quantity because Tim gave too many answers. Jack asked "have you heard that?", Tim simply replied "Yes, I heard or no, I did not hear". He didn't need to answer "something close". Tim is said to be doing the flouting maxim of quantity because it does not follow the principles of cooperation. According to Yule (1996: 37) the maxim of quantity is the speaker should make the contribution more informative than is required. The speaker only provides information that the speaker knows and needs by the listener, the speaker need not give too little or too much information to the listener. Tim carried out the flouting maxim of quantity in accordance with what was described by Levinson (1983:110) flouting maxim of quantity is the simple and repeat the 
similar utterance without giving require information, it is absolutely no communicative import because the hearer does not get anything about the information.

Based on the explanation above, it can be concluded that the implicature behind Tim's words is that both he and Jack are confused by what they heard. However, they both seemed to know that what they heard was the voice of a pokemon.

Here, Tim did the flouting maxim of quantity because he was confused and didn't know for sure what he heard. Or maybe Tim wants to give an explanation about something he heard but he is not sure about. However, Jack looks like he understands what Tim means even though Tim has done the flouting maxim of quantity. And it doesn't seem to be a problem for Jack when they're having a conversation.

$\begin{array}{lcc}\text { 00:06:08 - 00:06:16 } & \\ \text { Jack } & : & \text { I'm worried about you. } \\ \text { Tim } & : & \text { This again? } \\ \text { Jack } & \text { Ok listen, everyone we know has left town } \\ \text { Tim } & : & \text { and now i'm leaving too. } \\ & & \begin{array}{l}\text { for you with the time that you got. That's what i'm } \\ \text { doing. You know i'm crushing it at work. Gonna get } \\ \text { that promotion real soon. }\end{array}\end{array}$

Analysis

From the conversation above, Jack did flouting maxim of quantity because there Jack gave too many answers. Tim asked "this again?", Jack actually simply answered "Yes or No". He doesn't need to answer "Ok listen, everyone we know has left town and now i'm leaving too." Jack is said to be doing the flouting maxim of quantity because he does not follow the principles of cooperation. According to Yule (1996: 37) the maxim of quantity is the speaker should make the contribution more informative than is required. The speaker only provides information that the speaker knows and needs by the listener, the speaker need not give too little or too much information to the listener. Jack did the flouting maxim of quantity as described by Levinson (1983:110) flouting maxim of quantity is the simple and repeat the similar utterance without giving require information, it is absolutely no communicative import because the hearer does not get anything about the information.

Based on the explanation above, it can be concluded that the implicature of Jack's words is that he is very worried about Tim's loneliness which will make Tim lonely or have no friends.

Here Jack does a flouting maxim of quantity trying to explain his worries about Tim. Tim who is one who doesn't have Pokemon or can't say Tim really doesn't have the desire to have Pokemon friends and that's what worries Jack. Jack will 
leave town and is very worried about Tim who will be alone without Jack and without pokemon friends. However, Tim still understands what Jack meant. And that was not a problem in their conversation. Even though Jack did the flouting maxim of quantity, when seen from Tim's response to Jack's words. Tim understands what Jack explained, although Jack's concern makes Tim feel a little annoyed. But that was not a problem in their conversation.

$\begin{array}{llr}\text { 00:06:22-00:06:32 } & \text { What's the promotion for an insurance } \\ \text { Jack } & : & \text { appraiser? Senior insurance appraiser? } \\ \text { Tim } & \text { No actually that's two steps up above } \\ \text { Jack } & \text { where i'm at right now. } \\ & \text { nou are gonna make me throw up. That's } \\ & \text { not a real thing. }\end{array}$

Analysis

From the conversation above, Tim did a flouting maxim of quantity because Tim gave too many answers. Jack asked, "What's the promotion for an insurance appraiser? Senior insurance appraiser? "Tim actually had to answer" what position will he get ". He doesn't need to answer "No actually that's two steps up above where I'm at right now." Tim is said to be doing the flouting maxim of quantity because it does not follow the principles of cooperation. According to Yule (1996: 37) the maxim of quantity is the speaker should make the contribution more productive than is required. The speaker only provides information that the speaker knows and needs by the listener, the speaker need not give too little or too much information to the listener. Tim carried out the flouting maxim of quantity in accordance with what was described by Levinson (1983:110) flouting maxim of quantity is the simple and repeat the similar utterance without giving require information, it is absolutely no communicative import because the hearer does not get anything about the information.

Based on the explanation above, it can be concluded that the implicature of Tim's words is that he is confused about answering Jack's question where Tim already knows that his answer will not make Jack satisfied.

Here Tim does the flouting maxim because he feels confused about Jack's question, because there Jack seems to want clarity from Tim about the work that Tim always uses as his shield when people ask him about Pokemon. Even though Jack did a flouting maxim of quantity, if seen from Jack's response to Tim's words, Jack understood what Tim explained even though it did not make him satisfied nor the answer he wanted and it was not a problem in their conversation. 
00:11:29 - 00:11:34

Yoshida

Tim

Yoshida
: $\quad$ If you don't mind me asking, how come you don't have a Pokemon?

I thought I remember Harry saying you wanted to be a Pokemon Trainer when you were young.

: Yeah, that didn't really work out. Uh, I work in insurance now, so...

: $\quad$ I understand.

But, Tim, please don't put this all on yourself. No one should go through this type of thing alone. If you are anything like your dad...

Analysis

From the above conversation, Tim did a flouting maxim of quantity because Tim gave too many answers. Yoshida asked "If you don't mind me asking, how come you don't have a Pokemon? I thought I remember Harry saying you wanted to be a Pokemon Trainer when you were young. "Tim should have replied," Yeah, that didn't really work out. ". He doesn't have to answer, "Yeah, that didn't really work out. Uh, I work in insurance now, so ...". Tim is said to be doing the flouting maxim of quantity because it does not follow the principles of cooperation. According to Yule (1996: 37) the maxim of quantity is the speaker should make the contribution more informative than is required. The speaker only provides information that the speaker knows and needs by the listener. The speaker need not give too little or too much information to the listener. Tim does the flouting maxim of quantity as described by Levinson (1983: 110) flouting maxim of quantity is the simple and repeat the similar utterance without giving require information, it is absolutely no communicative import because the hearer does not get anything about the information.

Based on the explanation above, it can be concluded that the implicature of Tim's words was that he didn't want anyone to discuss it even though it was Yoshida. Tim always feels uncomfortable when someone asks about their Pokemon friends.

Here Tim does the flouting maxim because in fact he really doesn't want to explain further what happened to him so he doesn't have any pokemon friends. The team also seemed to feel a does not like when someone asked about their Pokemon friends and always explained about their work in order to avoid questions about Pokemon friends that they didn't have. Even though Tim did a flouting maxim of quantity when viewed from Yoshida's response to Tim's answer, it showed that Yoshida understood Tim's intentions so Yoshida tried to give a little advice to the Team. However, that was not a problem in their conversation. 
00:15:01-00:15:11

$\begin{array}{lcc}\text { Tim } & : & \text { Wait, what? } \\ \text { Lucy } & : & \text { Harry was onto something big. Real big. } \\ & \begin{array}{l}\text { And then all of a sudden, his car crashes over a } \\ \text { bridge. I think not. Something's rotten, and I'm } \\ \text { gonna get to the bottom of it. }\end{array} \\ \text { Tim } & \begin{array}{l}\text { Hey, look, I barely know the guy. I haven't } \\ \end{array} & \text { seen him in years. }\end{array}$

Analysis

From the conversation above Lucy did flouting maxim of quantity because Lucy gave too many answers. Tim asked "Wait, what?", Lucy should just have answered "Harry was onto something big". She doesn't need to answer "Harry was onto something big. Real big. And then all of a sudden, his car crashes over a bridge. I think not. Something's rotten, and I'm gonna get to the bottom of it ". Lucy is said to be doing the flouting maxim of quantity because she doesn't follow the principles of cooperation. According to Yule (1996: 37) the maxim of quantity is the speaker should make the contribution more informative than is required. The speaker only provides information that the speaker knows and needs by the listener, the speaker need not give too little or too much information to the listener. Lucy does the flouting maxim of quantity as described by Levinson (1983: 110) flouting maxim of quantity is the simple and repeat the similar utterance without giving require information, it is absolutely no communicative import because the hearer does not get anything about the information.

Based on the explanation above, it can be concluded that the implicature of Lucy's words is that she is very aware of the news about Harry and is trying to get further information about Harry.

Here Lucy is doing flouting maxim of quantity because basically she is an intern reporter at one of the big companies in ryme city. She does have quite a lot of information about Harry that Tim does not know as his son. When Lucy did the flouting maxim of quantity, Tim seemed a little confused by the meaning of Lucy's words. Though Lucy meant for Tim to provide information to him about Harry's disappearance. But even if it's like that, it becomes a problem in their conversation.

\section{CONCLUSIONS}

By thorough observation and analysis, Detective Pikachu Movie has 30 data in the form of dialogues that contained the flouting maxim of quantity carried out by the characters in Detective Pikachu Movie. Of the 30 data that have been found, the author has analyzed them to find answers to two research questions that discuss the flouting maxim of quantity and the response from the listener.

From those 30 data about the flouting maxim of quantity from Detective Pikachu Movie, there are many cooperative principles that have been flouted by 
the characters. Almost all of the characters in the movie flouted the maxim of quantity. The characters are said to be flouting the maxim of quantity because they are in the dialogue that occurs. They are too much or too little in providing information. When viewed from the comparison of the dialogue in the movie, giving too much information is more often done by the characters than giving too little information.

From the 30 data that contain the flouting maxim of quantity, it can be seen how the listener responds when a speaker does a flouting maxim of quantity. Almost all listeners are not bothered by the presence of a speaker flouting the maxim of quantity in their dialogue. Although there are some who feel confused by this, it does not make their dialogue not work well. Listeners can still respond well when there are speakers who do the flouting maxim of quantity.

\section{REFERENCES}

Brown, Y. (1983). Discourse Analysis. Cambridge: Cambridge University.

Creswell, J. W. (2014). Research Design. London: SAGE.

Cutting, J. (2008). Pragmatics and Discourse. London: Routledge.

Djadasudarman, F. (2012). Wacana dan Pragmatik. Bandung: Refika Aditama.

Edi. (2012, Maret 01). Aspek-aspek pragmatic: Tindak tutur, Praanggapan, Implikatur. Retrieved from Wordpress: https://edisuryadimaranaicindo.wordpress.com/2012/03/01/aspek-aspekpragmatik-tindak-tutur-praanggapan-dan-implikatur-2

Grice, H. (1989). Studies in the Way of Words. Cambridge: Harvard University Press.

Grice, H. P. (1989). Studies in the Way of Words. Cambridge: Harvard University Press.

Levinson, S. C. (1983). Pragmatics. New York: Cambridge University.

Parker, F. (1986). Linguistics for Non Linguists. London: Taylor and Francis.

Thomas, J. (1995). Meaning in Interaction to Pragmatics. New York: Routlegde.

Thompson, B. D. (1997). Film Art: an Introduction. New York: McGraw-Hill.

Yule, G. (1996). Pragmatic. New York: Oxford University Press. 